\title{
Impact of COVID-19 on personal insurance sales - Evidence from Germany
}

http://doi.org/10.21272/fmir.5(1).80-86.2021

Gerriet Hinrichs, ORCID: https://orcid.org/0000-0002-4490-3856

PhD Candidate, Szent István University, Budapest, Hungary

Henning Bundtzen, ORCID: https://orcid.org/0000-0002-0098-8886

$\mathrm{PhD}$ Candidate, Szent István University, Budapest, Hungary

\begin{abstract}
The occupation of insurance agent involves establishing a relationship of trust with the customer and providing personal and customized advice as a prerequisite for successful sales. This paper summarizes the scientific discussion about the occupation of an insurance salesperson. Coronavirus disease 2019 restrictions have limited face-to-face meetings and complicated large parts of this occupation. The main purpose of the research is to analyze the impact of these restrictions on the sales of 130 insurance branches, comparing the sales of 2019 and 2020 separately by insurance type. This period was chosen because it allows for the usual seasonal volatility to be taken into account. To differentiate according to the type of insurance sold is therefore of interest, because large differences with regard to demand generation and the use of existing customer relationships are to be expected. It shows that consulting-intensive new contracts in the life insurance segment declined noticeably, while the upselling of existing contracts in the non-life insurance segment increased significantly. The research empirically confirms and theoretically proves the importance of personal contact with the customer in the sale of life insurance and pension plans as well as the value of technical tools in upselling non-life policies. The insights from this exceptional coronavirus disease 2019 episode can also be useful in normal times for sales managers in managing insurance premiums to be sold. Further research as well as practitioners should concentrate on shock-resistant consulting approaches and techniques.
\end{abstract}

Keywords: insurance sales, COVID-19, salesforce, personal selling, non-life insurance.

JEL Classification: G22, G52, I13.

Cite as: Hinrichs, G., Bundtzen, H. (2021). Impact of COVID-19 on personal insurance sales - Evidence from Germany. Financial Markets, Institutions and Risks, 5(1), 80-86. http://doi.org/10.21272/fmir.5(1).80$\underline{86.2021}$

Received: 1 February 2021

Accepted: 1 March 2021

Published: 30 March 2021

Copyright: (C) 2021 by the authors. Licensee Sumy State University, Ukraine. This article is an open access article distributed under the terms and conditions of the Creative Commons Attribution (CC BY) license (https://creativecommons.org/licenses/by/4.0/)

\section{Introduction}

What for heaven's sake does COVID-19 have to do with insurance sales? To answer this initially not absurd question, one must take a closer look at the occupation of insurance agent. In Germany, there are currently 198,500 self-employed and 32,000 employed insurance salespersons (GDV, 2020). The special characteristic of insurance sales is that, as in the case of network goods (Katz \& Shapiro, 1985), the product only achieves value when there are at least two customers with each additional customer providing additional value. In the case of insurance, among other things, through better calculation options and thus more favorable prices. In an insurance company, therefore, sales also have a production function.

\section{Literature Review}

Insurance sales is an almost 200-year-old occupation that hardly anyone knows objectively, but which is burdened with many prejudices (Lee et al., 2007). First, therefore, it must be clarified what constitutes the occupation of insurance agent. Information on this can be found on official websites in Germany as well as in the USA. The German one (BERUFENET, 2021) presents the tasks and activities according to Table 1 under the occupational 6864 and classification number of 72132-108. 
Table 1. Tasks of an insurance salesperson according to (Berufenet, 2021)

\begin{tabular}{|l|l|}
\hline \multicolumn{1}{|c|}{ Tasks } & \multicolumn{1}{|c|}{ Activity } \\
\hline $\begin{array}{l}\text { Inform and advise customers about pension options and insurance } \\
\text { products }\end{array}$ & $\begin{array}{l}\text { ・ Identify needs and gaps in coverage } \\
\text { Examine risks } \\
\text { Present insurance products } \\
\bullet \text { Plan customer-oriented pension options and insurance solutions }\end{array}$ \\
\hline Process offers and contracts for insurance and pension options & $\begin{array}{l}\text { ・ Provide quotes for insurance products } \\
\text { - Arrange and close contracts for insurance and pension plans } \\
\text { C Capture insurance proposals }\end{array}$ \\
\hline $\begin{array}{l}\text { Determine payment of insurance coverage in the event of a claim, } \\
\text { process compensation for policyholders }\end{array}$ & \\
\hline $\begin{array}{l}\text { Sell additional asset and investment products as well as real estate, if } \\
\text { applicable }\end{array}$ & \\
\hline Serve customer base, acquire new customers & \\
\hline
\end{tabular}

Source: (Berufenet, 2021).

Accordingly, the main task is to advise customers by analyzing their insurance situation and coverage needs and to cover or handle these needs. Interestingly, the occupation is not listed in the main group of sales, these begin with a 6 , but in business organization, accounting, law, and administration. This could also be a reason why the focus in the description of the occupation is on consulting and administration and actual sales are presented as a minor matter. The Occupational Information Network of the U.S. Department of Labor (National Center for O*NET Development, 2021) is a system for classifying occupational skills and requirements and describing occupations (Peterson et al., 2001). Occupation ID 41-3021.00 describes the most common 8 tasks of an insurance salesperson according to Table 2 .

Table 2. Tasks of an insurance salesperson according to (O*NET, 2021)

\begin{tabular}{|l|l|}
\hline Task & Details \\
\hline Customize & insurance programs to suit individual customers, often covering a variety of risks \\
\hline Sell & various types of insurance policies to businesses and individuals \\
\hline Explain & features, advantages, and disadvantages of various policies to promote sale \\
\hline Perform & administrative tasks, such as maintaining records and handling policy renewals \\
\hline Seek out & new clients and develop clientele by networking to find new customers \\
\hline Call on & $\begin{array}{l}\text { policyholders to deliver and explain policy, to analyze insurance program and suggest additions or changes, or to change } \\
\text { beneficiaries }\end{array}$ \\
\hline Confer & with clients to obtain and provide information when claims are made on a policy \\
\hline Interview & $\begin{array}{l}\text { prospective clients to obtain data about their financial resources and needs, the physical condition of the person or property to be } \\
\text { insured, and to discuss any existing coverage. }\end{array}$ \\
\hline
\end{tabular}

Source: (O*NET, 2021).

Here, too, the focus is on advising customers and adapting insurance products to their needs. However, the importance of the sales factor also becomes clear here, which is reflected in the points Sell, Seek out and Call on. Also science fortunately deals with the occupation in sales. (Moncrief et al., 2006) found 12 factors, from which a sales job is composed, by questioning salesperson to 105 activities. Table 3 shows these factors in descending complexity.

Table 3. Tasks of a salesperson according to (Moncrief et al. 2006)

\begin{tabular}{|r|l|l|}
\hline \multicolumn{2}{|c|}{ Factor } & \multicolumn{1}{c|}{ Tasks } \\
\hline 1 & Relationship selling & Build trust, "Read the customer", close the sale, plan + call \\
\hline 2 & Promotion / Sales Service & Advertising, familiar with product, handle passive orders \\
\hline 3 & Entertain customers & Invite customers into a relaxed environment \\
\hline 4 & Prospecting & Call on potential accounts, acquire new customers \\
\hline 5 & Computer & Apply latest technology, use databases, create presentations \\
\hline 6 & Travel & Night on the road, travel out of town \\
\hline 7 & Training / Recruiting & Recruit and train new sales Reps \\
\hline 8 & Delivery & Deliver product or samples (esp. in retail and wholesale) \\
\hline 9 & Product Support & Check function of product at customer and adjust if necessary \\
\hline 10 & Educational Activities & Further education, attend meetings and trainings \\
\hline 11 & Office & Generate reports, general correspondence \\
\hline 12 & Channel support & Establish relationships with distributors, train middlemen \\
\hline
\end{tabular}

Source: (Moncrief et al. 2006).

(Hain et al., 2019) recently conducted a similar factor analysis on this basis with 161 activities and defined only 6 factors. However, the previously performed qualitative analysis to determine the activities led to some 
less concrete expressions. Furthermore, the aggregation of the activities to only 6 factors results in generic terms, which seem difficult to summarize for the practitioner. For example, factor 1 consists of the activities "maintain marketing displays" as well as "train new sales reps" with similar factor loadings. These are activities, which only with a lot of good will show a commonality.

(Duska, 2005) states that it is the task of an insurance professional to educate and persuade people that -life insurance as an example- their families or others need some security in case of a premature death. Referring to the requirements for the professionalization of this occupation formulated in 1915 by Solomon Huebner, formerly dean of the American College of Life Underwriters, Duska also mentions the requirement of expert knowledge for the salesperson. Expert knowledge should offer the customer clear added value, especially in the form of up-to-dateness. By focusing completely on customer benefits, the "strictly selfish commercial view" should be abandoned, and loyalty should also be shown to competitors as part of the industry. The positive correlation of product and procedural knowledge on sales success could be proven by (Leigh et al., 2014) and (Mariadoss et al., 2014). (Jasmand et al., 2012) showed that ambidextrous behavior in the sense of a balanced relationship between service and sales is at the expense of efficiency but has an overall positive effect on performance. Long-term success is usually the result of a good customer relationship. (DominiqueFerreira, 2018) has demonstrated the immense influence of the insurance intermediary on the customer's decision process when buying insurances. (Che et al., 2018) showed a positive effect of the strength of tie between salesperson and customer on both sales' effectiveness and sales revenue. This tie is mediated by the amount of information the seller has about the customer, the degree of persuasiveness, and network benefits resulting from a kind of commercial friendship. Already (Boles et al., 2000) have proven in the context of relationship selling that interaction intensity and mutual disclosure of seller and buyer are decisive for the sales performance on a sample of 487 insurance salespeople. (Bergeron \& Vachon, 2008) even found that the sense of humor of the financial advisor has a positive effect on the customer's perceived satisfaction and purchase intention and willingness to recommend. In addition to the activities shown in Tables 1 and 2, the scientific analysis by (Moncrief et al., 2006) reveals that the use of the latest technology and thus new forms of communication is of great importance. Since sales is a critical component of any company's success (Williams et al., 2009), salesforce has always been equipped with this technology very early on, if not first, for reasons of efficiency. (Christ \& Anderson, 2011) point out that creative early adoption and adaptation to selling have been the essence of the sales occupation since the 1850s. The reason for this is not only a more efficient way of working but also value creation for the customer by better analysis of his needs, better presentation of information or a simplified buying processes (Singh et al., 2019).

Let's move on to COVID-19. The aim of the corona restrictions imposed by governments worldwide was to minimize the transmission of the virus by reducing personal contacts with the possibility of aerosol exchanges (Ferguson et al., 2020). As of 3/22/2020, outdoor stays were only allowed alone, in pairs, or with people from one's own household. Insurance agencies had to close regionally or were no longer accessible to customers (Federal Press Office, 2020). A month later, agencies were allowed to reopen, but contact restrictions still applied and the public was encouraged to have minimal face-to-face contact (The Federal Government, 2020). As of May 6, people nationwide were again allowed to meet with two other households in public spaces. While infection numbers were moderate during the summer, they increased exponentially again beginning in September (The Federal Government, 2021).

The call for fewer contacts, the closure of branch offices, and non-verbal communication made more difficult by the obligation to wear a mask have severely impacted insurance sales. Both contact with new customers, intensive analysis of the customer's insurance needs, and persuasive elements had to be switched within a noticeably short time to technical solutions that were available but had not yet been used to any significant extent by customers or salespersons. These limitations lead to the following hypotheses:

Hypothesis 1: Insurance sales have declined due to COVID-19.

Hypothesis 2: Since selling new insurance contracts requires more consulting services compared to upselling a current policy, the impact of COVID-19 on new contracts is stronger than on upselling.

Hypothesis 3: Since the sale of life insurance requires a higher level of consulting services compared to non-life insurance, the impact of COVID-19 on sales of life insurance policies is greater than on the non-life insurances. 


\section{Materials and Methods}

This study examined the average number of insurance policies sold by 130 insurance branches (1-7 salespersons) of a large German mutual insurance company. The monthly figures for 2019 were compared with those for 2020. The shutdown caused by COVID-19 started in Germany on March 16, 2020. A distinction is made between non-life insurance and life insurance. In the area of non-life insurance, an additional distinction is made between new contracts and upselling.

\section{Results}

The total number of new non-life contracts sold by the branches studied was 26,042 in 2019 and 30,587 in 2020. Figure 1 shows the monthly performance throughout the year. Median values per branch are shown in Figure 2.

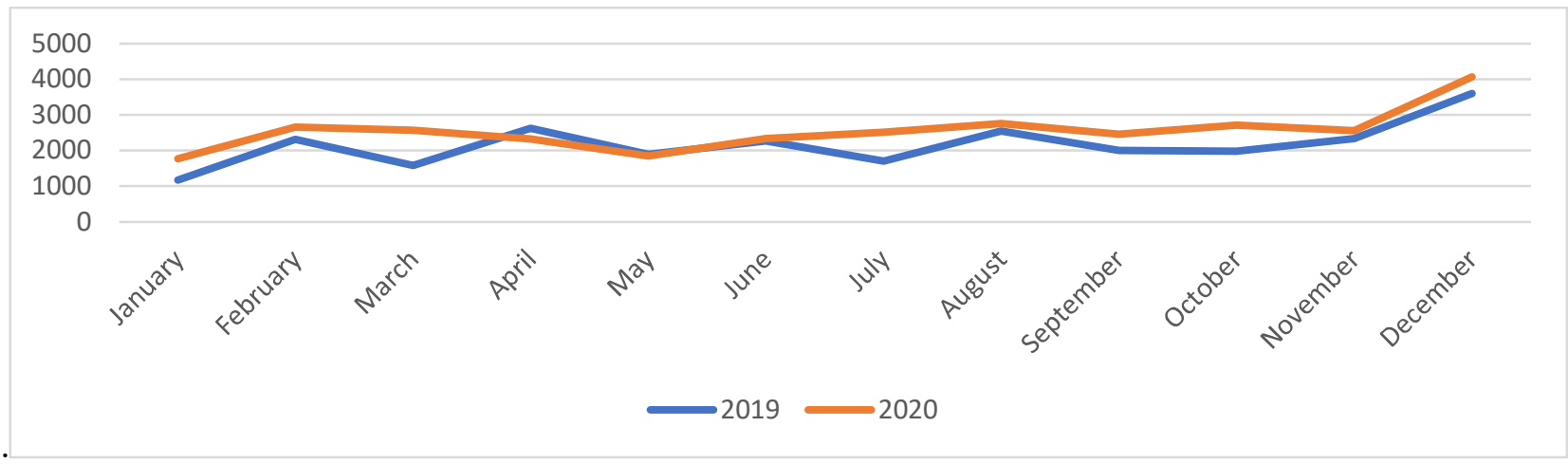

Figure 1. Sales performance non-life new contracts; own calculations

Source: Authors' calculations.

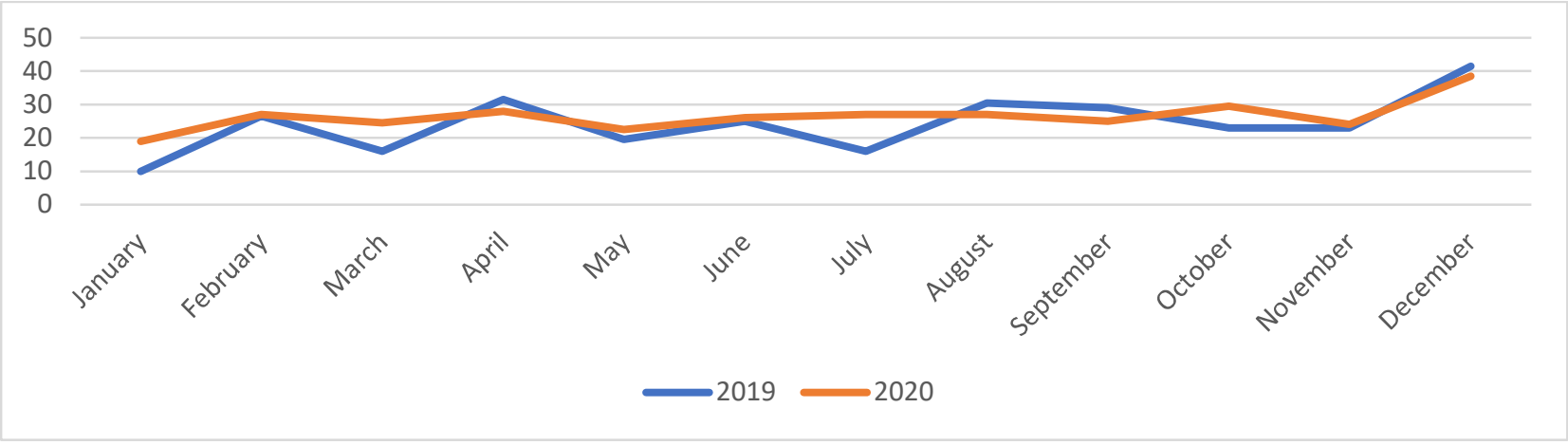

Figure 2. Median sales performance per branch non-life new contracts; own calculations

Source: Authors' calculations.

The total number of non-life upselling sold in the studied branches amounted to 16,950 pieces in 2019 and 20,613 pieces in 2020. This represents an increase of 22\%. Figure 3 shows the monthly performance throughout the year. Median values per branch are shown in Figure 4.

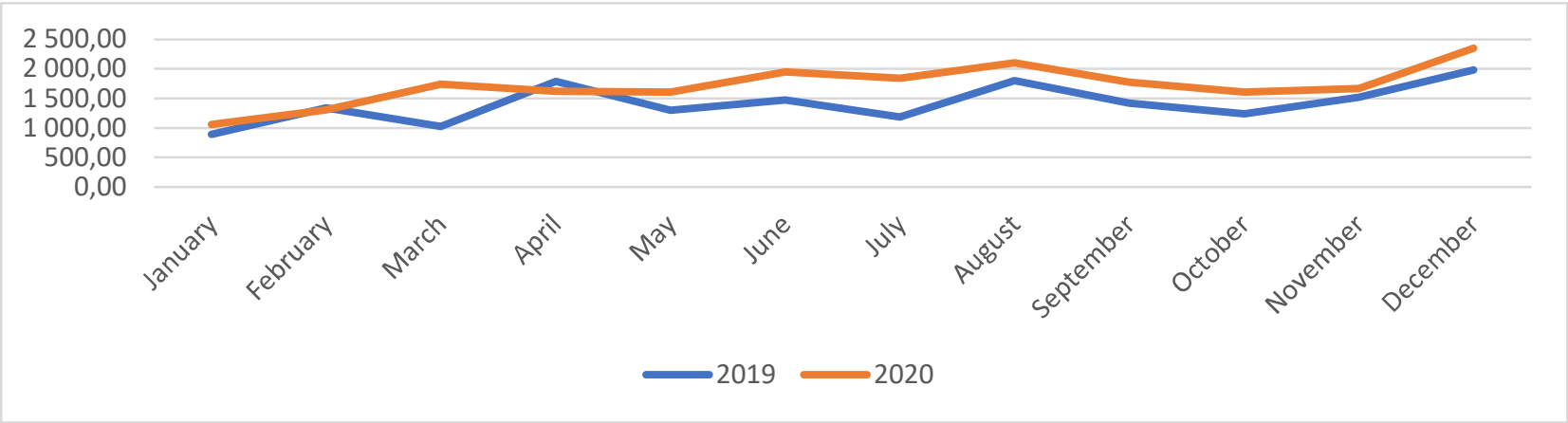

Figure 3. Sales performance non-life upselling; own calculations

Source: Authors' calculations. 


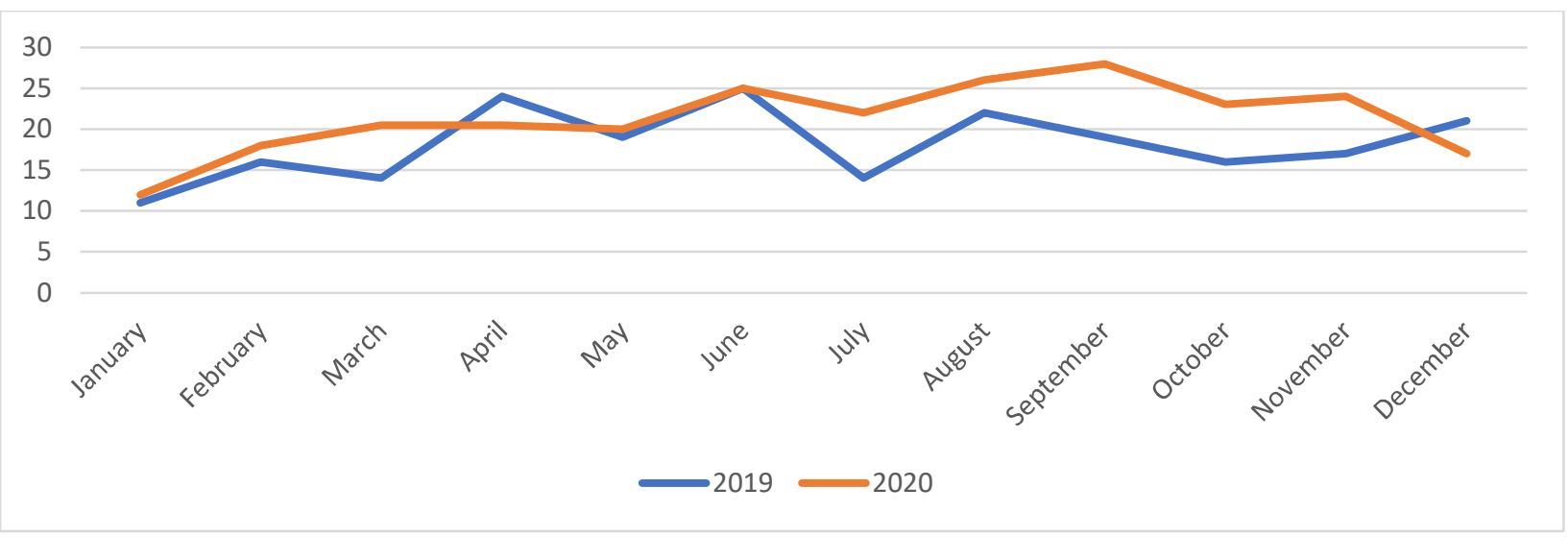

Figure 4. Median sales performance per branch non-life upselling; own calculations

Source: Authors' calculations.

The total number of new life policies sold in the analyzed branches was 3,014 in 2019 and 3,269 in 2020. This represents an increase of $8 \%$. Figure 5 shows the monthly performance throughout the year. Median values per branch are shown in Figure 6.

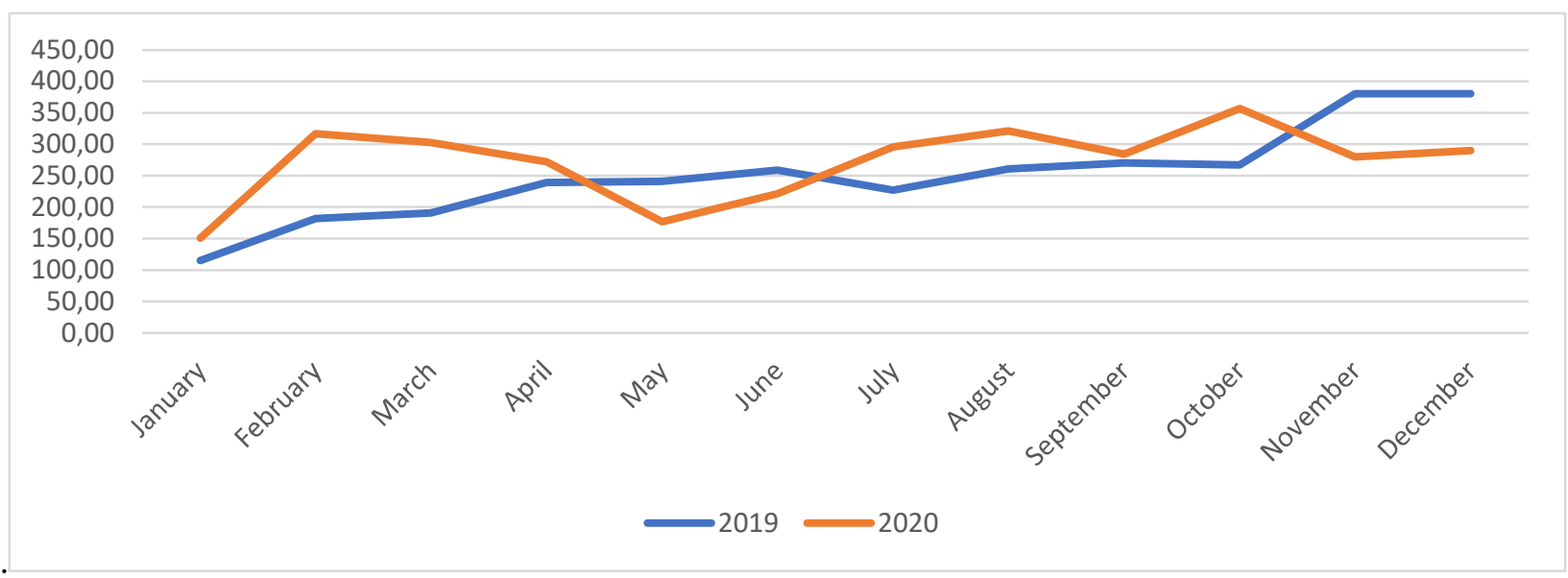

Figure 5. Sales performance life new contracts; own calculations

Source: Authors' calculations.

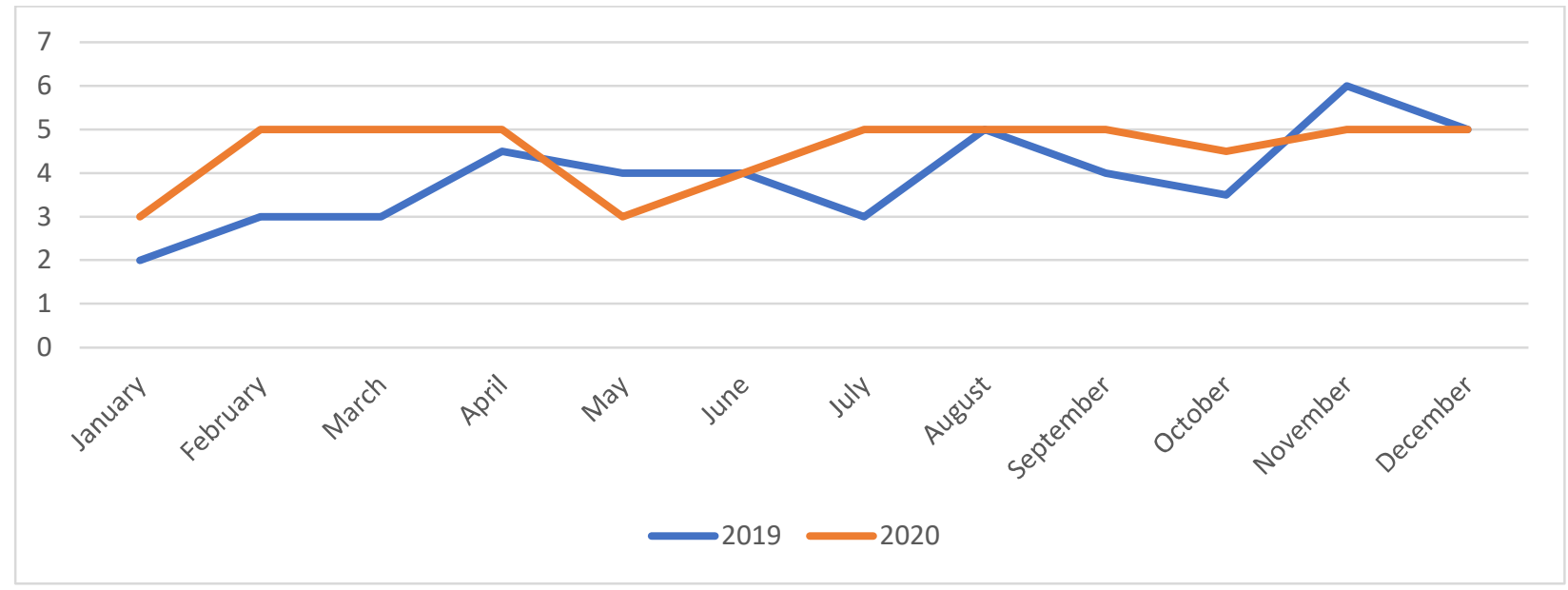

Figure 6. Median sales performance per branch life new contracts; own calculations

Source: Authors' calculations.

\section{Discussion}

Sales of non-life new policies in 2020 were significantly better than in 2019 , with $17.5 \%$ more policies sold 
year-on-year, but still showed a clear dip after the first lockdown in March. It is important to note here the median value, which was even below the previous year's level despite higher sales figures, particularly in August and September. This shows that the generally higher success of these months was not generated evenly by the entire sales team. Reasons for this could be found in differences in customer loyalty (Che et al., 2018) and the adoption of alternative technical sales tools (Christ \& Anderson, 2011).

The curve for upselling of existing non-life contracts from 2020 shows that after a certain phase of orientation, organization and active adjustment to the new situation, upselling is significantly higher than in the previous year, and even significantly higher overall year-on-year at $+21.6 \%$. The median values show a response from the entire team, with the value in December falling below the previous year's value. This could be due to the fact that either motivation has waned in some branches or the upselling potential in the customer base has simply been exhausted. Hypothesis 2 can therefore be confirmed.

The performance of newly sold life insurance policies shows that this business area was significantly impacted by the officially imposed Corona restrictions. While more insurance policies were sold across the board in the first quarter, sales slumped significantly with both the first and second Corona waves, in both cases below the previous year's level. The median curve shows a similar picture here, suggesting that the entire sales team was equally affected. This suggests that life insurance is more difficult to sell through technical solutions than nonlife contracts. The full-year comparison shows an increase of $8.5 \%$, which is significantly lower than the increase in the non-life segment. While hypothesis 3 can be confirmed, hypothesis 1 must be rejected.

\section{Conclusion}

It appears that, especially during the first lockdown, the technical possibilities first had to be adopted and strategies developed, which were then consistently applied. Few branches succeeded in increasing new contract sales in the non-life area, but those that did were even more successful. In non-life upselling, there was a significant increase compared to the previous year, which can be attributed to technical resources such as phone, which can be operated by all salespersons, and the corresponding good availability of customers by phone. Despite further technical possibilities, the sale of life insurances still appears to be a personal contact business. Further research as well as practitioners should concentrate on shock-resistant consulting approaches and techniques.

Author contributions: conceptualization, Hinrichs, G., Bundtzen, H.; methodology, Hinrichs, G., Bundtzen, H.; validation, Hinrichs, G., Bundtzen, H.; formal analysis, Hinrichs, G., Bundtzen, H.; investigation, Hinrichs, G., Bundtzen, H.; resources, Hinrichs, G., Bundtzen, H.; data curation, Hinrichs, G.; writing - original draft preparation, Hinrichs, G.; writing - review and editing, Bundtzen, H.; visualization, Hinrichs, G., Bundtzen, H.; supervision, Hinrichs, G., Bundtzen, H.; project administration, Hinrichs, G., Bundtzen, $\mathrm{H}$.

\section{References}

1. Bergeron, J., \& Vachon, M.-A. (2008). The effects of humour usage by financial advisors in sales encounters. International Journal of Bank Marketing, 26(6), 376-398. https://doi.org/10.1108/02652320810902424

2. Berufenet. (2021). Versicherungsvertreter/in. Bundesagentur für Arbeit [Insurance agent. Federal agency for work]. Retrieved from: https://berufenet.arbeitsagentur.de/berufenet/faces/index: BERUFENETJSESSIONID=m-pAHblfj8V9s6uRJARoBhs4B2O6zcPuNUwC7YXgcqezCt-Mfp3F!329116 517?path $=$ null/sucheAZ/kurzb esch reibung $\& \mathrm{dkz}=6881 \&$ let $=\mathrm{V}$

3. Boles, J., Brashear, T., Bellenger, D., \& Barksdale, H. (2000). Relationship selling behaviors: antecedents and relationship with performance. Journal of Business \& Industrial Marketing, 15(2/3), 141-153. https://doi.org/10.1108/08858620010316840

4. Che, Y., Li, Y., Fam, K.-S., \& Bai, X. (2018). Buyer-seller relationship, sales effectiveness and sales revenue: a social network perspective. Nankai Business Review International, 9(4), 414-436. https://doi.org/10.1108/NBRI-09-2017-0051

5. Christ, P., \& Anderson, R. (2011). The impact of technology on evolving roles of salespeople. Journal of Historical Research in Marketing, 3(2), 173-193. https://doi.org/10.1108/17557501111132136 
6. Dominique-Ferreira, S. (2018). The key role played by intermediaries in the retail insurance distribution. International Journal of Retail \& Distribution Management, 46(11/12), 1170-1192. https://doi.org/10.1108/IJRDM-10-2017-0234

7. Duska, R. (2005). The History and Role of the Insurance Professional. In M. L. Pava (Ed.), Research in Ethical Issues in Organizations: v. 6. Crisis and opportunity in the professions (Vol. 6, pp. 43-66). Elsevier JAI. https://doi.org/10.1016/S1529-2096(05)06003-7

8. The Federal Government. (2020, April 15). Telephone conference between the Federal Chancellor and the Heads of Government of the Länder on April 152020 [Press release]. https://www.bundesregierung.de/resource/blob/975226/1744550/4e256a620f61e3154bf8b2bf310837c2/2020 -04-15-beschluss-bund-laender-eng-data.pdf?download=1

9. The Federal Government. (2021). Die aktuellen Fallzahlen in Deutschland und weltweit [The current case numbers in Germany and worldwide]. Retrieved from: https://www.bundesregierung.de/bregde/aktuelles/fallzahlen-coronavirus-1738210

10. Federal Press Office. (2020, March 22). Press Release Number 104/20 of 22 March 2020: Meeting between Federal Chancellor Merkel and the Minister-Presidents of the Länder to discuss coronavirus [Press release]. Retrieved from: https://www.bundesregierung.de/resource/blob/975226/1733914/ fa51a075a455ada $\underline{58 \mathrm{bb} 478 \mathrm{c} 0561 \mathrm{~b} 43 \mathrm{f} 7 / 2020-03-23 \text {-beschluss-laender-statement-kanzlerin-eng-data.pdf?download }=1}$

11. Ferguson, N. M., Laydon, D., Nedjati-Gilani, G., Imai, N., Ainslie, K., Baguelin, M., Bhatia, S., Boonyasiri, A., Cucunubá, Z., \& Cuomo-Dannenburg, G. (2020). Impact of non-pharmaceutical interventions (NPIs) to reduce COVID-19 mortality and healthcare demand. Imperial College COVID-19 Response Team. Imperial College COVID-19 Response Team, 20. Retrieved from: https://spiral.imperial.ac.uk/handle/10044/1/77482

12. GDV. (2020). Statistisches Taschenbuch der Versicherungswirtschaft 2020 [Statistical Pocket Book of the Insurance Industry 2020]. Retrieved from: https://www.gdv.de/de/zahlen-undfakten/publikationen/statistisches-taschenbuch

13. Hain, J. S., Rutherford, B. N., \& Hair Jr, J. F. (2019). A taxonomy for financial services selling. Journal of Personal Selling \& Sales Management, 39(2), 172-188. https://doi.org/10.1080/08853134.2018.1544078

14. Jasmand, C., Blazevic, V., \& Ruyter, K. de (2012). Generating sales while providing service: A study of customer service representatives' ambidextrous behavior. Journal of Marketing, 76(1), 20-37. https://doi.org/10.1509/jm.10.0448 